\title{
PROFESSIONAL MOTIVATION OF FUTURE TEACHERS: PSYCHOLOGICAL AND PEDAGOGICAL ASPECT
}

\section{ПРОФЕСІЙНА МОТИВАЦІЯ МАЙБУТНІХ УЧИТЕЛІВ: ПСИХОЛОГО-ПЕДАГОГІЧНИЙ АСПЕКТ}

UDC 159.947.5:378.013.42

DOI https://doi.org/10.32843/2663-

5208.2020 .20 .13

\section{Bilous R.M.}

PhD (Psychology),

Head of the Department of Psychology,

Pedagogy and Philosophy

Kremenchuk Mykhailo Ostrohradskyi

National University

Soshenko S.M.

$\mathrm{PhD}$ (Pedagogy),

Associate Professor at the Department of Psychology, Pedagogy and Philosophy Kremenchuk Mykhailo Ostrohradskyi National University

\section{Sizova K.L.}

D. of Sc. (Philology),

Head of the Philology and Publishing Department

Kremenchuk Mykhailo Ostrohradskyi National University
The paper provides a theoretical digression of the «professional motivation» concept, its role in the formation of the individual professional qualities. The novelty of the study is to determine the psychological and pedagogical aspects of future teachers' professional motivation: the presence of optimal and negative motivational complexes; irrelevance for students of the need for security; the dominance of medium levels of motivation to succeed and avoid failure over high ones. According to the essence of the concept of «professional motivation», social request, purpose and content of professional activity of the future specialist, the needs of students in knowledge and skills, psychological and pedagogical support includes targeted, semantic, procedural, evaluative and effective components. In order to form professional motivation it is necessary to simulate some realities, in particular, the unity of general didactic and specific principles will promote personal and professional development. The obtained data allowed stating the insufficient formation of professional motivation. The necessity of psychological and pedagogical support of professional motivation formation is substantiated, which will promote high-quality theoretical and practical training and development of adequate self-assessment and self-esteem of teachers. Psychological and pedagogical support allows organizing imitation by students of real professional activity and provides mastering of acting ways of the specialist that provides training for the future professional activity. Psychological and pedagogical support of the educational process activates the development of professional motivation, promotes the formation of professional competencies, improves the quality of education and brings students closer to future professional activities.

Key words: motivation, professional motivation, future teachers, psychological and pedagogical support, training, project.

у статті подано теоретичний екскурс поняття «просресійна мотивація», простежено їі роль у формуванні індивідуальних професійних якостей майбутніх учителів. Наукова новизна дослідження полягає у визначенні психолого-педагогічних аспектів професійної мотивації майбутніх учителів, а саме: наявності оптимальних та негативних мотиваційних комплексів; незадоволеності потреби у безпеці; домінуванні середніх рівнів мотивації до успіху та уникнення невдач над високими. Відповідно до сутності поняття «професійна мотивація», соціального запиту, мети та змісту профресійної діяльності майбутнього спеціаліста у галузі освіти, потреб здобувачів освіти у актуальних знаннях та вміннях, психолого-педагогічна підтримка містить цільову, семантичну, процедурну, оціночну та есрективну компоненти. Для формування професійної мотивації необхідно змоделювати деякі реалії, зокрема єдність загальнодидактичних та конкретних принципів, що сприяє особистісному та професійному розвитку. Отримані у процесі емпіричного дослідження дані дали змогу констатувати недостатнє формування профессійної мотивації. Обгрунтовано необхідність психолого-педагогічного супроводу формування просресійної мотивації, що сприятиме якісній теоретичній та практичній підготовці, а також розвитку адекватної самооцінки майбутніх учителів. Психолого-педагогічний супровід дає змогу організувати результативне наслідування здобувачами освіти реальної професійної діяльності та створює умови для засвоєння навичок, що забезпечують підготовку до майбутньої просресійно діяльності. Психолого-педагогічний супровід навчального процесу активізує розвиток профресійної мотивації, сприяє формуванню профресійних компетентностей, поліпшує якість університетської освіти та наближає студентів до майбутньої професійної діяльності у галузі освіти

Ключові слова: мотивація, професійна мотивація, майбутні вчителі, психолого-педагогічний супровід, тренінг, проєкт.
Introduction. The modern globalization and transformation processes are deepening the global socio-economic crisis, which leads to the restructuring of the labor market, improvement of existing educational programs for training, including educational profile. The growth of requirements for future teachers, finding ways to improve their professional ability and competitiveness involves improving the quality of training, encourages higher education institutions to form students professional motivation for better understanding the essence of professional activity, acquiring the necessary skills to work online space, implementation of the educational projects results in the field of business and industry.

Modernization of higher professional education in Ukraine as a fundamental component of a holistic system of continuing education in a systemic crisis of society is a requirement of our time. Young professionals have great potential, creative thinking, are easier to learn and better adapted to work in the enterprise, have new knowledge and advanced technologies. However, they lack the work experience, specific knowledge and skills required by employers. As a result, the youth unemployment rate is higher than the national average (see table 1). 
Economic activity of the population by age groups (in \%)

Table 1

\begin{tabular}{|l|c|c|c|}
\hline & Economic activity level & Employment level & Unemployment rate \\
\hline Whole population & 64,3 & 59,2 & 7,9 \\
\hline \multicolumn{3}{|c|}{ Including by age groups } \\
\hline 15-24 years & 41,7 & 33,9 & 18,6 \\
\hline $25-29$ years & 79,7 & 72,4 & 9,2 \\
\hline $30-34$ years & 83,0 & 76,9 & 7,4 \\
\hline Working age & 72,7 & 66,5 & 8,6 \\
\hline
\end{tabular}

According to the State Statistics Service, $72,4 \%$ of young people under the age of 25-29 have a job, 9,2\% could not find a job, but among the general population the unemployment rate was $7,9 \%$ [8].

Unconscious or non-independent choice of profession, employment problems reduce interest in the profession to the point of abandoning it altogether. Therefore, it is important to have a conscious professional motivation that needs correction and management by teachers, students and the state in general.

Literature review. Problems of professional motivation, its role in the formation of consciousness, personality development are considered in the works of R. M. Badubi [1], R. Bilous and D. Pysarenko [2].

In the psychological and pedagogical literature, the phenomenon of motivation is interpreted as:

- factors that determine human behavior (K. Madeleine, J. Godfrey);

- a set of motives (K. Platonov);

- the process of mental regulation of activity (M. Magomet-Eminov);

- the process of action of the motive and mechanisms of origin, direction and methods of specific activities (I. Dzhidaryan);

- system of processes responsible for motivation, activity (V. Vilyunas).

Motivation helps not only to encourage activity in life, but to be successfully realized in professional activities. M. Cochran-Smith defines the dynamic aspect of responsibility: initiation, formation of intention and choice of a specific action; realization of intention; rethinking the act after implementation. Thus responsibility is a semantic formation of the person; the motivational function of motivation is realized through meaning [6].

Professional motivation is constantly or temporarily influenced by external and internal factors, which leads to its relative stability, but at the same time dynamism. That is, depending on the psychological characteristics of the person and his previous experience, the professional motivation of the individual may persist for a long time or change rapidly. The general pattern of professional motivation is its gradual structure (see fig. 1).

The implementation of professional activity and its effectiveness depends on the motives and strength with which they influence. The regularity of the influence of the actual motives' force on the efficiency of activity is manifested in its best quality at an average level of motivation and a decrease in performance at high and low levels. Weak abilities to the profession can compensate for the presence of motivation; lack of motivation cannot be replaced. In addition, an important factor in effective activity is the satisfaction of the individual with work.

Thus, professional motivation is one of the most important factors in the effectiveness of professional activity and human satisfaction with their job.

There are three components in the structure of professional motivation:

1) internal motivation arises as a result of human needs, associated with the process and result of work, it is carried out without external pressure and contains psychological characteristics of the individual (professional interests, social motives);

2) external positive motivation - material incentives, career growth, approval from colleagues and staff, prestige;

3) external negative motivation - the desire to avoid punishment, criticism, condemnation, fines. These components act simultaneously, but depending on the situation, a certain type of motivation prevails [5].

R. M. Badubi within the study of the motivation of achievement identified [1]:

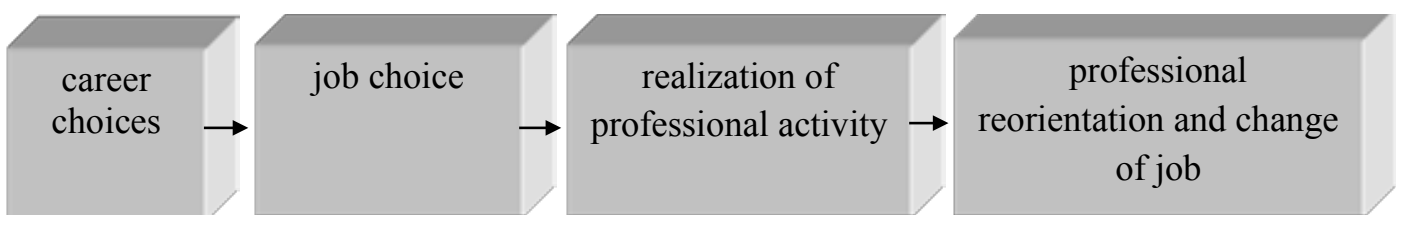

Fig. 1. The general pattern of professional motivation development 
1) internal motivation - aimed at the process of activity (interest and satisfaction with it), focus on the result of the activity (the desire to perform a specific activity to meet other needs);

2) external motivation: requirements from others and from oneself (motivation of duty).

Internal needs are a factor in the development of personality and have their own characteristics: the desire for new information; activity; knowledge of the world and behaviour in it; self-actualization. A person with a developed internal motivation is characterized by interest in the process of activity, and not only in its results.

Scientists divide the structure of professional motivation into components:

1) motives of direct labor activity: motivation of public character; receiving material benefits; meeting the need for self-actualization, self-expression, self-realization, as well as public recognition and respect;

2) motives for job choosing: positive or negative assessment of factors: wages, benefits, convenient transportation, aesthetics of the workplace and the presence of harmful production, reliability and prestige of the company, psychological climate in the team, control system; assessment of one's own capabilities (state of health, availability of abilities and professionally important qualities, levels of education, propensity to work without stress and at a certain pace); assessment of compliance of the peculiarities of the job to one's own interests (career and professional growth, managerial work, manifestations of personal initiative) [5].

Thus, professional motivation has a complex structure of coexistence and interaction of different motives - external and internal, positive and negative.

In recent years, there has been a fundamental revision of approaches to education of teachers $[3 ; 4 ; 10]$ Problems of this branch, competences of specialties, research of professionally important qualities of teachers are in the centre of scientific attention [6, 9]. Scientists offer fundamental changes in the content of teachers' education [4], study the features of training teachers in the Digital Era [10], substantiated the need for pedagogical support dual training [7], identified ways to increase the practical orientation of training future teachers [3].

However, R. Bilous and D. Pysarenko noted that the identification of professional motivation allows improving the learning process depending on the importance of subjects for future professional activity [2, p. 109].

It is during the student years that the beginning of entering the profession and the formation of professional motives, the formation of the personality of the specialist in general, which encourages the theoretical and empirical study of professional motivation of future teachers and actualizes the research topic.
The purpose of the article is to determine the need for psychological and pedagogical support for the formation of professional motivation of future teachers.

Results of research. The professional motivation of 162 students majoring in 0.14 «Secondary education» of $\mathrm{KrNU}$ was studied.

According to the method «Motivation of professional activity» (K. Zamfir, modification of A. Rean) the optimal motivational complex was found in $57 \%$ of respondents (internal positive motivation prevails over external one); neutral (equivalent effect of all types of motivation on the personality) - in 33\%; $10 \%$ have a negative motivational complex (external negative motivation predominates). Such individuals cannot adequately perceive criticism, they need to be constantly in their own comfort zone; they need help in finding intrinsic motivation to succeed professionally.

The method of diagnosing the degree of satisfaction of basic needs emphasizes the dominance of material security, the desire to have a high salary (43\%), $23 \%$ of respondents who need respect from others (desire to gain recognition, improve skills and competencies, status, influence) and $22 \%$ of students for whom self-realization is important (development of abilities, desire for something new, work for self-realization). For $13 \%$ of future teachers, the importance of interpersonal needs is noted (warm relations in the team, understanding for others). The lack of need for security attracts attention, because it is the desire to secure a future, strengthen status, and avoid trouble.

According to the method of T. Ehlers, we state the advantage of the average level of motivation to succeed (60\% of respondents) at $30 \%$ high, i.e. respondents are able to take risks to achieve the desired goal, tend to focus on their own strength, flexibly and persistently achieve the planned. Only $10 \%$ of the sample is apathetic, passive about life, no desire to make own efforts.

These methods correlate with the methods of diagnosing failure avoidance (according to T. Ehlers): the average level of motivation to avoid failure prevails $(67 \%)$ and high $(23 \%)$, which confirms the presence of students' prudence, ability to calculate their strength and moderate risk. However, $10 \%$ of respondents have a low level of avoidance of failures, such individuals go to their goal, despite obstacles and capable of high risk.

The method of measuring achievement motivation confirms the ability of $65 \%$ of respondents to adequately assess their own goals and consciously take risks with confidence in achieving success, which will help achieve high performance, selfimprovement, feasibility, increasing self-esteem.

Thus, the obtained data allow stating the insufficient formation of professional motiva- 


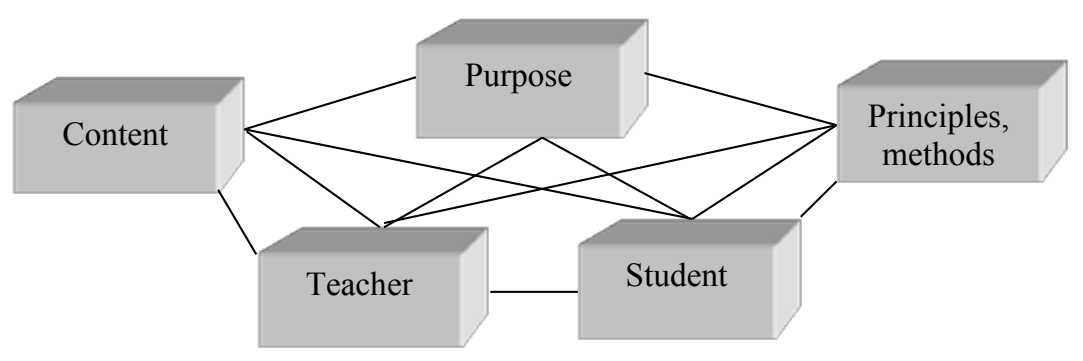

Fig. 2. Structural and logical scheme of psychological and pedagogical support

tion of future teachers, which necessitates psychological and pedagogical support for the formation of professional motivation of students.

Now, when the development of technology is constantly advancing, an important problem is the training of professionally motivated qualified teachers.

The institution of higher education should develop in future teachers those qualities that would help make the work of an teacher more efficient. However, it is the development of professional motivation of students, awareness of their own professional opportunities will determine the ways of their further professional growth; will promote the formation of adequate self-esteem.

The state standards of higher education in Ukraine, educational and professional programs for bachelors state that the future teacher must not only gain a set of knowledge, skills and abilities, professional experience, but also be a fully developed person capable of being a creative, purposeful specialist. That is why the integrated application of competency, systematic, personality-oriented approaches should ensure the successful formation of professional motivation of future teachers.

Modern requirements of the Ministry of Education and Science of Ukraine to the educational process in the context of a combination of theoretical and practical forms of work, update the cycle of training sessions. Training, as a form of problem-based learning, is focused on working out and consolidating effective patterns of behaviour, the mostactive participation of students, exchange of experiences and the use of effective group interaction. For this purpose it is expedient to apply such methodical receptions, as lecture, method of cases, modelling of practical situations, brainstorming, discussion, situational-role games, etc.

Implementation of support involves the presence of a centre of psychological support for participants in pedagogical interaction or the creation of active socio-psychological training groups, which has some differences from socio-psychological training. Common to these forms of support is the humanistic organization of psychocorrectional procedures, and the difference is the maximization of spontaneity of group interaction with a focus on the study of personal prob- lems of the subject of communication, because through the identification of personal causes of difficulties expands «» of another person.

The main principles of psychological support should be:

1) observance of sincerity, trust, creative position, confidentiality, activity of participants, which has a positive effect on the initial interaction;

2) playful nature allows you to relieve natural tension and anxiety, create a favorable psychological climate for immersion in one's own personality and awareness of the factors of professional motivation.

Perceptions of the professional activity of future teachers reflect the degree of adequate expectations of students from the future profession. If a student has a formed image of the profession, knows and develops professionally important qualities, tries to master the necessary skills this will allow him to be a highly qualified and successful professional.

The formation of future teachers professional motivation , as a multilevel structure, depends on the organization of psychological and pedagogical support (see fig. 2).

In order to form professional motivation it is necessary to simulate some realities, in particular, the unity of general didactic and specific principles (focus on future professional activity, professional mobility, practical training in the use of information technology) will promote personal developmentandfurtherprofessionaldevelopment.

The use of the following methods will strengthen the motivation of students: game design (introduction of elements of business game in a specific situation of professional activity combines cognitive activity, fundamental and professional training) and situational tasks (application of the acquired basic theoretical knowledge in the process of solving real problems provides mastery of theoretical information and practical skills).

Thus, psychological and pedagogical support for the development of professional motivation contributes to a clear understanding of students' prospects for future professional activity, the application of interdisciplinary knowledge, intellectual skills, and forms personal and professional qualities, bringing students closer to future professional activity in education field. 
Conclusions. Thus, the optimization of training of future teachers is a requirement of time. The development of professional motivation as a system of incentives for professional self-determination will help the specialist to understand the essence of the profession, external and internal risk factors and career success, provided quality performance of production functions, acquisition of skills necessary for self-fulfilment.

Psychological and pedagogical support of the educational process activates the development of professional motivation, promotes the formation of professional competencies, improves the quality of education and brings students closer to future professional activities.

\section{REFERENCES:}

1. Badubi R. M. Theories of Motivation and Their Application in Organizations: A Risk Analysis. International Journal of Innovation and Economic Development. 2017. Vol. 3. Iss. 3. P. 44-51.

2. Bilous R. M., Pysarenko D. O. Theoretical and methodological aspects of personality motivation. Engineering and educational technologies. 2017. Vol. 4 (20). P. 105-117. [in Ukrainian].

3. Cochran-Smith M. Policy, Practice, and Politics in Teacher Education. 2006. Thousand Oaks, CA: Corwin Press. 2006.

4. Koster B., Dengerink, J. J. Professional standards for teacher educators: how to deal with complexity, own- ership and function. Experiences from the Netherlands. European Journal of Teacher Education. 2008. Vol. 31. Iss. 2. P. 135-149.

5. Musset P. Initial teacher education and continuing training policies in a comparative perspective. Current practices in OECD countries and a literature review on potential effects Directorate for Education working paper $\mathrm{n}^{\circ} 48$. URL: https://www.oecd-ilibrary.org/ docserver $/ 5 \mathrm{kmbphh} 7 \mathrm{~s} 47 \mathrm{~h}$-en.pdf?expires= $1608576458 \& i d=i d \& a c c n a m e=$ guest $\&$ checksum $=$ 4325329 C 6 FF 0762592 F B 750 C 9 B F 52 CA 4 (12.11.2020).

6. Rockoff J., Jacob B., Kane T., Staiger D. Can You Recognize an Effective Teacher When You Recruit One? National Bureau of Economic Research: Working Paper. 2008. P. 1-56.

7. Shmeleva A., Sizova K., Soshenko S. Implementation of dual education elements into electrical engineers training. Proc. of the Int. Conf. MEES 2019, Kremenchuk, P. 332-336, September 23-25, 2019.

8. State Statistics Service of Ukraine. The main indicators of the labor market in 2000-2019. URL: http://www.ukrstat.gov.ua/operativ/operativ2007/rp/ean/ ean_u/arh_osp_rik_u.htm [in Ukrainian] (05.11.2020).

9. Stuart, J., Tatto M. T. Designs for initial teacher preparation programmes : an international view. International Journal of Educational Research. 2000. Vol. 12. P. 493-514.

10. Sykes G., Bird T., Kennedy M. Teacher Education: Its Problems and Some Prospects. Journal of Teacher Education. 2010. Vol. 61(5). P. 464-476. 